\title{
Conformational NMR Study of Bistriazolyl Anion Receptors
}

\section{Damjan Makuc, ${ }^{1,2}$ Tamara Merckx,${ }^{3}$ Wim Dehaen ${ }^{3}$ and Janez Plavec ${ }^{1,2,4, *}$}

\author{
${ }^{1}$ Slovenian NMR Centre, National Institute of Chemistry, Hajdrihova 19, 1000 Ljubljana, Slovenia \\ ${ }^{2}$ EN $\rightarrow$ FIST Centre of Excellence, Trg Osvobodilne fronte 13, 1000 Ljubljana, Slovenia \\ ${ }^{3}$ Molecular Design and Synthesis, Department of Chemistry, KULeuven, Celestijnenlaan 200F, 3001 Leuven, Belgium \\ ${ }^{4}$ Faculty of Chemistry and Chemical Technology, University of Ljubljana, Večna pot 113, 1000 Ljubljana, Slovenia \\ * Corresponding author: E-mail: janez.plavec@ki.si. \\ Tel: +38614760353
}

Received: 14-01-2016

Dedicated to late Professor Janez Jamnik.

\begin{abstract}
Conformational features of pyridine- and pyrimidine-based bistriazolyl anion receptors dissolved in acetonitrile- $\mathrm{d}_{3}$ were assessed by multidimensional, heteronuclear NMR spectroscopy. NOESY correlation signals suggested preorganization of both host molecules in solution in the absence of anions. In addition, only a single set of signals was observed in the ${ }^{1} \mathrm{H}$ NMR spectra, which suggested a symmetrical conformation of anion receptors or their conformational exchange that is fast on the NMR time-scale. Furthermore, the predominant conformations of the pyridine- and pyrimidine-based anion receptors are preserved upon addition of chloride, bromide, and acetate anions. Chemical shift changes observed upon addition of anions showed that the NH (thio)urea and triazole protons are involved in anion-receptor interactions through hydrogen bonding.
\end{abstract}

Keywords: Anion receptors, conformational analysis, host-guest systems, NMR spectroscopy

\section{Introduction}

Small molecules that have appropriate functional groups or binding moieties may serve as sensors for anions, and this has been the focus of intensive research during the last decades. ${ }^{1}$ Anions play important roles in biological and chemical processes, and are ingredients of pollutants released in the environment for example; therefore anion sensing remains a topic of interest. Often hydrogen-bonding is involved in the binding event of a potential receptor molecules and an anion, and this is mostly occurring through classical $\mathrm{N}-\mathrm{H}$ and $\mathrm{O}-\mathrm{H}$ hydrogen bond donors of receptor molecules. However, recently substantial attention has gone to compounds containing polarized $\mathrm{C}-\mathrm{H}$ bonds, ${ }^{2,3}$ such as 1,2,3-triazoles ${ }^{4,5}$ due to their large dipole moment (up to $5 \mathrm{D}$ ) with the positive end at the 5-hydrogen atom of the heterocycle. ${ }^{6 \#}$ The ver- satility of the click reaction ${ }^{7}$ and alternative strategies ${ }^{8,9}$ towards a very wide variety of 1,2,3-triazoles has stimulated our research endeavors. Previously we have described bistriazolyl anion receptors with a central pyridine ${ }^{10 \#}$ and a central pyrimidine. ${ }^{11}$

In this study we have analyzed the prospective conformational preorganization and conformational changes of earlier synthesized bistriazolyl anion receptors ${ }^{11}$ upon addition of various anionic species using NMR techniques. Bistriazolyl anion receptors differ in their middle aromatic ring, compound $\mathbf{1}$ contains a pyridine and $\mathbf{2}$ contains a pyrimidine moiety (Figure 1). These two moieties could have a different effect on the preorganization, which is crucial to achieve high binding affinities of receptors. We were intrigued by their conformational features, but unfortunately we were not able to obtain large enough crystals for single-crystal X-ray diffraction. Alternatively, 


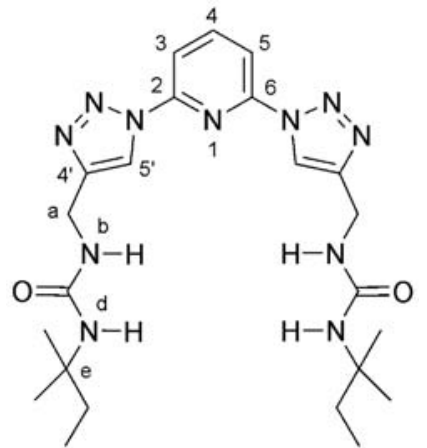

1

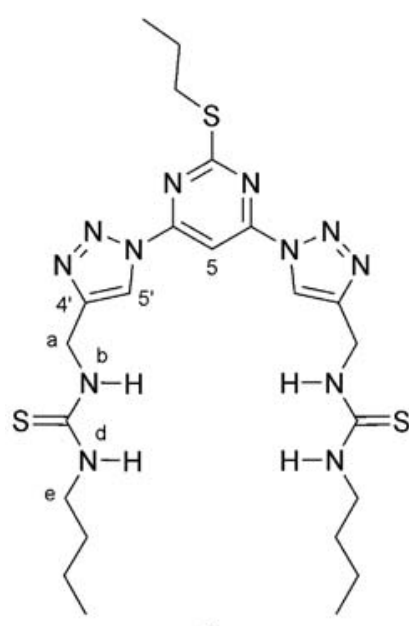

2

Figure 1. Anion receptors $\mathbf{1}$ and $\mathbf{2}$ with atom numbering.

a conformational study was performed by means of NMR spectroscopy. We were encouraged by the observations in our studies on indole anion receptors, which showed different conformational preferences in the absence and in the presence of anions. ${ }^{12-14}$ The conformational preferences of bistriazolyl anion receptors and their complexes with anions were herein correlated with the electronic properties of pyridine, pyrimidine, triazole and (thio)urea moieties with the intention of obtaining new insight and therefore give fresh stimulus to the design of anion-specific receptors.

\section{Results and Discussion}

The receptors $\mathbf{1}^{10 \#}$ and $\mathbf{2}^{11}$ were prepared as published previously. The pyridine-based host $\mathbf{1}$ contains several single bonds, which allow a large rotational flexibility. Nevertheless, conformational preferences along four bonds are expected to influence the binding affinity of the receptor, and involve relative orientations of pyridine and triazole rings as well as preferences along the methylene groups connecting triazole rings and urea moieties (rotations along $\mathrm{C}-2-\mathrm{N}-1$ ' and $\mathrm{C}-4$ '- $\mathrm{C}-\mathrm{a}$ bonds denoted by red arrows in Figure 2). The conformational features of the pyridine-based receptor were assessed by 2D NOESY experiments (Figure S1 in Supplementary material). Interestingly, the triazole H-5' proton showed no NOESY correlation signals with the pyridine $\mathrm{CH}$ protons, which sugge-

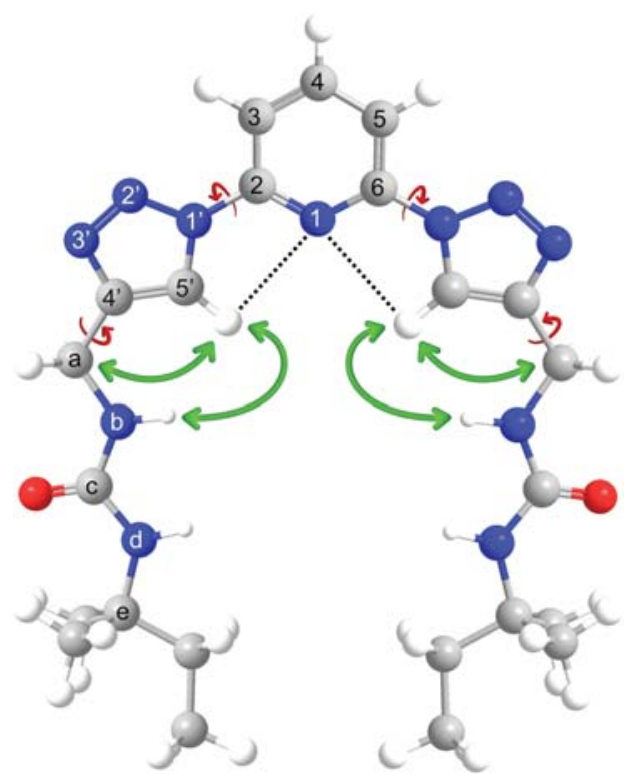

Figure 2. Predominant conformation of $\mathbf{1}$ in acetonitrile- $\mathrm{d}_{3}$ at 298 K based on NOESY cross-peaks; the key NOESY correlations are marked with green arrows. Red arrows indicate four main single bonds, which are expected to define the binding affinity of the receptor.

sted a mutual orientation of the two heterocyclic rings in which triazole protons are predisposed for hydrogen bonding with N-1 of pyridine (Figure 2).

In addition, NOESY cross-peaks were observed between triazole $\mathrm{H}-5$ ' protons and urea moieties (H-b) as well as methylene $\mathrm{H}$-a protons. These NOESY results corroborate preorganization of pyridine-based host $\mathbf{1}$ as shown in Figure 2. Only a single set of signals was observed for both triazole-urea moieties attached to C-2 and C-6 in the ${ }^{1} \mathrm{H}$ NMR spectrum, which suggests a symmetrical conformation of both triazole moieties in host $\mathbf{1}$ or their conformational exchange that is fast on the NMR time-scale.

Interaction of anions with receptor molecules was followed through changes in chemical shifts as concentration of tetrabutylammonium salts was increased. Chemical shift changes observed upon addition of one equivalent of chloride anions clearly corroborate that urea H-b and $\mathrm{H}-\mathrm{d}$ protons, and triazole $\mathrm{H}-5$ ' protons are involved in anion-receptor interactions through hydrogen bonding (Figure 3). The preorganized conformation of $\mathbf{1}$ in the absence of anions is predisposed for anion binding. Additionally, a significant deshielding of triazole $\mathrm{H}-5$ ' proton of up to $0.6 \mathrm{ppm}$ was observed, while pyridine and alipha- 
tic protons showed only negligible chemical shift changes. Similar chemical shifts changes were observed upon addition of bromide anions, as urea and triazole protons showed moderate deshielding between 0.3 and $0.5 \mathrm{ppm}$, while the other proton chemical shift changes were insignificant. Major deshielding of urea protons H-b and H-d was observed in the presence of acetate anions $(\Delta \delta 1.5$ and $1.0 \mathrm{ppm}$, respectively), whereas triazole $\mathrm{H}-5$ ' proton showed minor chemical shift change (Figure 3), which could be attributed to the planarity of acetate anions and their predisposition for bidentate interactions with the urea moieties in $\mathbf{1}$.

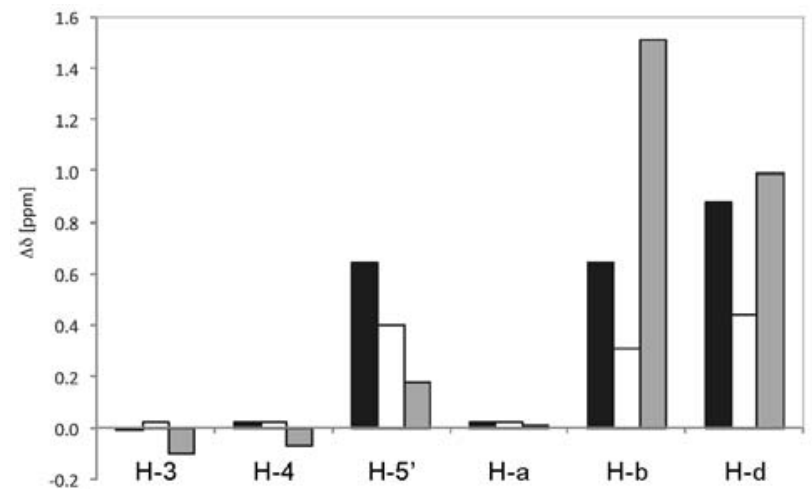

Figure 3. ${ }^{1} \mathrm{H}$ NMR chemical shift changes, $\Delta \delta=\delta$ (in the presence of anions) $-\delta$ (in the absence of anions), induced by addition of one

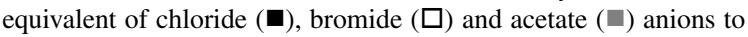
receptor $\mathbf{1}$.

2D NOESY spectrum of the 1- $\mathrm{Cl}^{-}$complex showed cross-peaks that were observed for the receptor in the absence of anions, which suggested that the predominant conformation of $\mathbf{1}$ is preserved upon addition of chloride anions (Figure S2). The most significant difference was increase in the volume integral of the correlation signal corresponding to the proximity of the triazole $\mathrm{H}-5$ ' and urea H-b protons (Figure 4). This observation could indicate that interactions between anions and H-5, H-b and $\mathrm{H}-\mathrm{d}$ led to a restriction of the rotational degrees of freedom along the C-4'-C-a single bond in $\mathbf{1}$. There were no NOESY cross-peaks that would suggest major changes of conformational features for the $1-\mathrm{Cl}^{-}$complex with respect to the conformation of host $\mathbf{1}$ in the absence of anions. Similarly, an increased volume of the H-5'-H-b NOESY cross-peak was observed upon addition of bromide and acetate anions to $\mathbf{1}$ (Figure 4), which also suggested that conformational preferences of $\mathbf{1}$ are preserved upon addition of anions.

A second type of bistriazolyl anion receptors contained a pyrimidine ring. The two electronegative nitrogen atoms in a pyrimidine ring polarize the $\mathrm{C}-\mathrm{H}$ bond at position 5, resulting in a stronger hydrogen bond donor capacity in comparison with benzene. The good anion binding

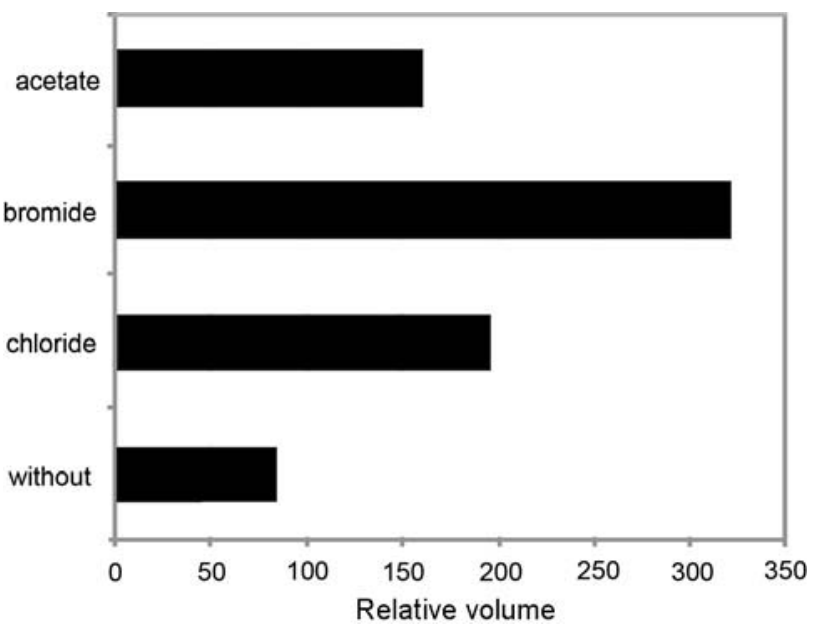

Figure 4. Relative volumes of the H-5'-H-b NOESY cross-peak in $\mathbf{1}$ in the absence and in the presence of different anions. NOESY spectra $\left(\pi_{\mathrm{m}} 200 \mathrm{~ms}\right)$ were acquired in acetonitrile- $\mathrm{d}_{3}$ at $298 \mathrm{~K}$. The cross-peak between triazole H-5' and methylene $\mathrm{H}$-a protons of $\mathbf{1}$ in the absence of anions was used as a reference, which was arbitrarily set to 100 units.

properties of pyrimidine together with the high binding affinities of several triazolophanes reported by Flood $e t$ $a l .{ }^{15,16}$ prompted us to synthesize 4,6-bis-(1,2,3-triazol-1yl)-pyrimidine receptors and analyze their anion recognition abilities. The binding affinities determined for the pyrimidine-based receptors were rather disappointing: the acyclic receptor 2 showed moderate binding affinities (e.g. $\log \left(K_{a}\right)=2.2$ for chloride and 1.9 for bromide anions, see supplementary material for details) and attempts to improve the binding properties by synthesizing cyclic derivatives were not successful. To find an explanation for these observations, we wanted to take a closer look at the possible conformations of receptor 2 . Unfortunately, crystals for X-ray crystallographic analysis could not be obtained. Alternatively, the conformation of the pyrimidinebased host $\mathbf{2}$ was further investigated by the use of NMR spectroscopy in solution.

Similar to $\mathbf{1}$, the pyrimidine-based host $\mathbf{2}$ exhibits multiple single bonds, two pyrimidine-triazole linkages and methylene connections between the triazole ring and thiourea moiety that are potentially critical for its anion binding and recognition abilities. The conformational properties of receptor $\mathbf{2}$ and its complexes with anions were first evaluated with 2D NOESY experiments. Surprisingly, no NOESY cross-peak could be observed between the triazole $\mathrm{H}-5$ ' protons and the pyrimidine $\mathrm{H} 5$ proton. Moreover, a NOESY correlation signal was observed between the triazole protons and the propylsulfanyl group (Figure S3). Accordingly, the pyrimidine-based host $\mathbf{2}$ is conformationally preorganized in solution in such a way that the pyrimidine $\mathrm{H} 5$ proton is oriented away from the triazole protons and thiourea moiety. The NOESY spectra confirmed the spatial proximity between the triazole $\mathrm{H}-5$, 
and methylene $\mathrm{H}-\mathrm{a}$ as well as thiourea $\mathrm{H}-\mathrm{b}$ protons (schematically presented in Figure 5). Nevertheless, the C-4'-C-a single bonds in 2 that link the triazole rings with the thiourea functionalities allow a quite unrestricted rotational flexibility. Similar NOESY cross-peaks were also observed for receptor $\mathbf{2}$ in the presence of chloride anions, suggesting that no conformational changes occur upon addition of the anions (Figure S4). A possible conformation, explaining these observations, is depicted in Figure 5.

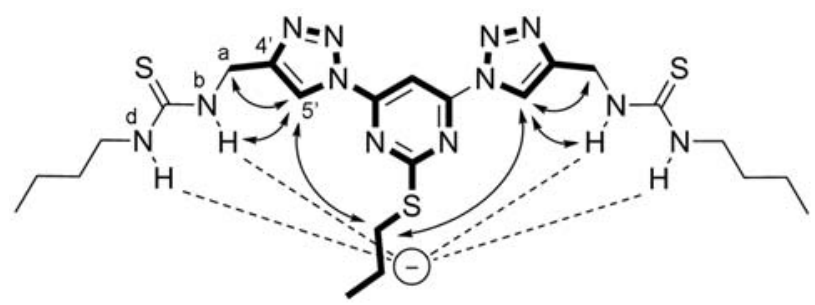

Figure 5. Predominant conformation and position of chloride anion in $\mathbf{2}-\mathrm{Cl}^{-}$complex in acetonitrile- $\mathrm{d}_{3}$ at $298 \mathrm{~K}$ based on chemical shift changes and NOESY cross-peaks $\left(\pi_{\mathrm{m}} 200 \mathrm{~ms}\right)$. The key NOESY correlations are marked with arrows.

Variable-temperature measurements were performed in order to reduce the rotational flexibility of host molecule. Cooling of the solution containing receptor $\mathbf{2}$ in the absence of anions down to $233 \mathrm{~K}$ resulted in two sets of signals for the thiourea $\mathrm{H}-\mathrm{b}$ and $\mathrm{H}-\mathrm{d}$ protons, methylene $\mathrm{H}-\mathrm{a}$ and $\mathrm{H}$-e protons, as well as triazole $\mathrm{H}-5$ ' protons in a ratio 3:2, which suggested the presence of two different conformers (Figure 6).

NOESY spectra at $233 \mathrm{~K}$ revealed no specific differences between the two species. The strong NOESY correlation signal between the well-resolved methylene

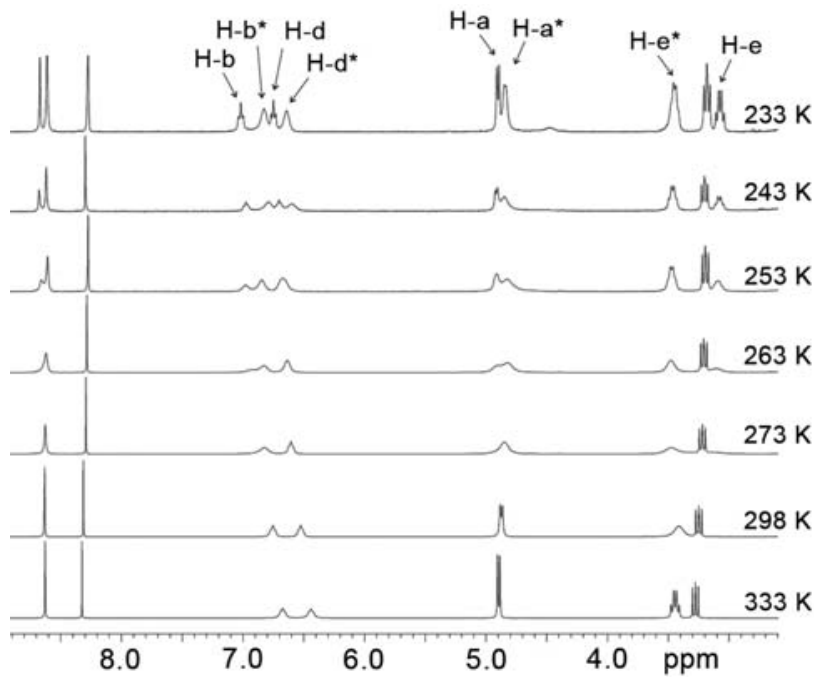

Figure 6. ${ }^{1} \mathrm{H}$ NMR spectra of $\mathbf{2}$ in acetonitrile- $d_{3}$ in the temperature range from 233 to $333 \mathrm{~K}$. Protons of the major species are denoted with asterisk $(*)$.
H-e protons of the butyl chain of the major and minor species suggested a dynamic exchange between the two conformers. The observed two sets of signals at $233 \mathrm{~K}$ can be caused by the formation of different aggregates, perhaps monomeric and dimeric complexes. The structural properties of two species observed at $233 \mathrm{~K}$ were therefore analyzed by the use of diffusion ordered spectroscopy (DOSY). However, no difference in the translational diffusion coefficients was observed, which indicated that both species are monomeric units $\left(D=0.4 \times 10^{-5} \mathrm{~cm}^{2} \mathrm{~s}^{-1}\right.$ at $233 \mathrm{~K}$ ). Unfortunately, no unambiguous evaluation of conformational properties of receptor 2 at $233 \mathrm{~K}$ could be achieved based on NOESY and DOSY spectra.

\section{Conclusion}

Multiple single bonds in the bistriazolyl anion receptor $\mathbf{1}$ with a central pyridine ring allow a fairly unrestricted rotational flexibility. However, 2D NOESY experiments showed only cross-peaks between the triazole and urea protons, and none between the pyridine and triazole protons, which suggested preorganization of the pyridine-based host $\mathbf{1}$ in such a way that the protons of the triazole ring are predisposed for hydrogen bonding with $\mathrm{N}-1$ of pyridine. In addition, only a single set of signals was observed in the ${ }^{1} \mathrm{H}$ NMR spectrum, which suggested a symmetrical conformation of host $\mathbf{1}$ or their conformational exchange that is fast on the NMR time-scale. Chemical shift changes observed upon addition of chloride, bromide, and acetate anions corroborated that $\mathrm{NH}$ urea protons and triazole protons are involved in anion-receptor interactions through hydrogen bonding. Furthermore, the correlation signals in 2D NOESY spectra of the anion-receptor complexes confirmed that the predominant conformation of $\mathbf{1}$ is preserved upon addition one equivalent of various anions. Contrary to our expectations, no NOESY cross-peak could be observed between the triazole $\mathrm{H}-5$ ' protons and the pyrimidine H-5 proton in pyrimidine-based receptor 2 . Nevertheless, receptor $\mathbf{2}$ is also preorganized in solution, with the pyrimidine proton oriented away from the triazole protons and thiourea moiety. Similar NOESY correlation signals were observed for receptor $\mathbf{2}$ in the presence of chloride anions, suggesting that no conformational changes occur upon addition of the anions. Our study demonstrates that combinations of pyridine or pyrimidine rings with triazole moiety offer intriguing scaffolds for the design of novel anion receptors that were preorganized in solution for hydrogen bonding interactions.

\section{Experimental}

The receptors $\mathbf{1}$ and $\mathbf{2}$ were prepared as reported in Supplementary materials (page S2). ${ }^{1} \mathrm{H}$ NMR and 2D NMR experiments including ${ }^{1} \mathrm{H}-{ }^{13} \mathrm{C}$ and heteronuclear 
single quantum correlation (HSQC) and heteronuclear multiple bond correlation (HMBC) were performed on a DD2 Agilent Technology NMR spectrometer at a frequency of $297.80 \mathrm{MHz}$ and $74.89 \mathrm{MHz}$ for ${ }^{1} \mathrm{H}$ and ${ }^{13} \mathrm{C}$ NMR, respectively. All data were recorded in acetonitrile$\mathrm{d}_{3}$ at $298 \mathrm{~K}$, unless stated otherwise; concentrations of receptors were $2 \mathrm{mM}$. Chemical shifts are referenced to the residual solvent signal of acetonitrile- $\mathrm{d}_{3}$. Individual resonances in the ${ }^{1} \mathrm{H}$ NMR spectra were assigned on the basis of the chemical shifts, signal integrations, multiplicity, and via ${ }^{1} \mathrm{H}-{ }^{13} \mathrm{C}$ direct and multi-bond correlation signals in $2 \mathrm{D}$ spectra. ${ }^{1} \mathrm{H}-{ }^{1} \mathrm{H}$ NOESY spectra were acquired using a mixing time of $200 \mathrm{~ms}$ at $298 \mathrm{~K}$. One equivalent of anions were added to anion receptor solution. All anions (chloride, bromide and acetate) were added as tetrabutylammonium salts.

\section{Acknowledgements}

The authors gratefully acknowledge the financial support of the Slovenian Research Agency, (ARRS, program no. P1-0242), EN-FIST Centre of Excellence and the European Cooperation in Science and Technology (COST Action CM1005 "Supramolecular Chemistry in Water").

\section{References}

1. P. A. Gale, C. Caltagirone, Chem. Soc. Rev. 2015, 44, 42124227. http://dx.doi.org/10.1039/C4CS00179F

2. B. P. Hay, V. S. Bryantsev, Chem. Commun. 2008, 24172428. http://dx.doi.org/10.1039/b800055g

3. C. Caltagirone, P. A. Gale, Chem. Soc. Rev. 2009, 38, 520563. http://dx.doi.org/10.1039/B806422A

4. K. P. McDonald, Y. Hua, A. H. Flood, in: P. A. Gale, W. De- haen (Ed.): Anion Recognition in Supramolecular Chemistry, Springer, Berlin Heidelberg, 2010, pp. 341-366.

http://dx.doi.org/10.1007/7081_2010_38

5. J. P. Byrne, J. A. Kitchen, T. Gunnlaugsson, Chem. Soc. Rev. 2014, 43, 5302-5325. http://dx.doi.org/10.1039/C4CS00120F

6. M. H. Palmer, R. H. Findlay, A. J. Gaskell, J. Chem. Soc., Perkin Trans. 2 1974, 420-428. http://dx.doi.org/10.1039/p29740000420

7. M. Meldal, C. W. Tornøe, Chem. Rev. 2008, 108, 2952-3015. http://dx.doi.org/10.1021/cr0783479

8. J. John, J. Thomas, W. Dehaen, Chem. Commun. 2015, 51, 10797-10806. http://dx.doi.org/10.1039/C5CC02319J

9. C. G. S. Lima, A. Ali, S. S. van Berkel, B. Westermann, M. W. Paixao, Chem. Commun. 2015, 51, 10784-10796. http://dx.doi.org/10.1039/C5CC04114G

10. T. Merckx, C. J. E. Haynes, L. E. Karagiannidis, H. J. Clarke, K. Holder, A. Kelly, G. J. Tizzard, S. J. Coles, P. Verwilst, P. A. Gale, W. Dehaen, Org. Biomol. Chem. 2015, 13, 16541661. http://dx.doi.org/10.1039/C4OB02236J

11. T. Merckx, P. Verwilst, W. Dehaen, Tetrahedron Lett. 2013, 54, 4237-4240. http://dx.doi.org/10.1016/j.tetlet.2013.05.133

12. D. Makuc, M. Lenarcic, G. W. Bates, P. A. Gale, J. Plavec, Org. Biomol. Chem. 2009, 7, 3505-3511. http://dx.doi.org/10.1039/b908947k

13. D. Makuc, Triyanti, M. Albrecht, J. Plavec, K. Rissanen, A. Valkonen, C. A. Schalley, Eur. J. Org. Chem. 2009, 48544866. http://dx.doi.org/10.1002/ejoc.200900721

14. N. Busschaert, L. E. Karagiannidis, M. Wenzel, C. J. E. Haynes, N. J. Wells, P. G. Young, D. Makuc, J. Plavec, K. A. Jolliffe, P. A. Gale, Chem. Sci. 2014, 5, 1118. http://dx.doi.org/10.1039/c3sc52006d

15. Y. Li, A. H. Flood, Angew. Chem. Int. Ed. 2008, 47, 26492652. http://dx.doi.org/10.1002/anie.200704717

16. Y. Li, A. H. Flood, J. Am. Chem. Soc. 2008, 130, 1211112122. http://dx.doi.org/10.1021/ja803341y

\section{Povzetek}

V prispevku smo s pomočjo večdimenzionalne, heteronuklearne NMR spektroskopije določili konformacijske lastnosti bistriazolilnih anionskih receptorjev dveh tipov, ki vsebujeta substituiran piridinski oziroma pirimidinski obroč. Glede na korelacijske signale v NOESY spektru smo ugotovili, da sta oba tipa anionskih receptorjev v raztopini v odsotnosti anionov predorganizirana. ${ }^{1} \mathrm{H}$ NMR spektru smo opazili en sam set signalov za obe triazolil-(tio)sečninski verigi, kar kaže na simetrično konformacijo anionskih receptorjev ali da je njihova konformacijska izmenjava hitra na časovni skali NMR. Prevladujoči konformaciji piridinskih in pirimidinskih bistriazolilnih anionskih receptorjev se po dodatku kloridnih, bromidnih in acetatnih anionov bistveno ne spremenita, torej je konformacija teh receptorjev predisponirana za vezavo anionov. Na podlagi sprememb kemijskih premikov ob dodatku anionov pa smo še pokazali, da so (tio)sečninski NH in triazolni CH protoni ključni za interakcije z anioni preko vodikovih vezi. 